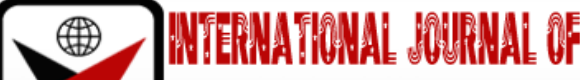

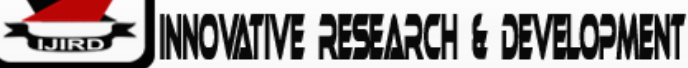

ISSN 2278-0211 (Online)

\section{Effects of Women Enterprise Fund's Training on Capital and Labour Resources of Women Grocery Micro-Entrepreneurs in Thika Sub-County, Kenya}

\author{
Michael Macharia Muraguri \\ Program Officer, Department of Health, PEMA, Kilifi County, Kenya
}

\begin{abstract}
:
There has been a great attention by the government of Kenya on women entrepreneurship over the last nine years. Several policies have been enacted that could support the growth and performance of women entrepreneurship in Kenya.The Women Enterprise Fund (WEF) was established in 2007 to assist women in the development of their enterprises. One condition of funding by WEF is that beneficiaries must first undergo capacity building before getting the funds. However, the effects of WEF's training remains unexplored in Kenya and in particular Thika Sub-County. This study sought to bridge the gap by establishing the effects of WEF's training on performance of women grocery microentrepreneursin Thika Sub-County in Kenya. The study examined the effects of WEF's training on the indicators of performance that is, labour and capital.It focused on two specific objectives to establish the effects of WEF's training on labour among women grocery micro-entrepreneurs and the effects of WEF's training on capital among women grocery micro-entrepreneurs.A cross-sectional descriptive survey research design was used. The sampling technique used wassimple random sampling, since it produced the most productive sample to test the research hypotheses. A sample size of 111 women entrepreneurs was used out of a population of 371 women entrepreneurs. Data was collected using structured questionnaires from the respondents. The study was guided by the human capital theory. Paired t-test and ordinate logistic regression were used to analyze quantitative data collected at 5\% significance level with the help of STATA software. Validity of the instruments was achieved through expert judgement of the research supervisors and WEF's officials. Reliability was tested by subjecting the instruments to a pilot study through the test-retest technique. The study established that the type of training had significant effect on the performance of women grocery microentrepreneurs. While the frequency of training had no significant effect on the sales of women grocery microentrepreneurs. From the study results, the researcher recommends for the performance of women micro-entrepreneurs to improve drastically WEF has to focus more on providing quality training especially market access skills. It is therefore, hoped that the outcomes and recommendations of this study will be of help to WEF and other women entrepreneurship stakeholders to address the performance challenges in Thika Sub-County and the nation at large.
\end{abstract}

Keywords: WEF's training, performance, micro-entrepreneurs, grocery

\section{Background of the Study}

The Women Enterprise Fund (WEF) was established by the Kenyan government through Legal Notice No. 147: Government Financial Management Regulations, 2007 (WEF, 2012). The enactment of Public Finance Management Act, 2012, classifies the body as a National Fund. As a flagship project under the social pillar in the Kenya vision 2030, WEF spearheads the realization of the $1^{\text {st }}$ and $3^{\text {rd }}$ Millennium Development Goals on Poverty Reduction and Gender Equality \& Women Empowerment respectively. The mandate of the Fund as stipulated in the Legal Notice No.147is to undertake the following (WEF, 2013),(1)Provide loans to credible micro-finance institutions (MFIs), registered non-governmental organisations (NGOs) undertaking micro financing, as well as savings and credit co-operative organisations (SACCOs) for on-lending to women enterprises;(2) Attract and facilitate investment in micro, small and medium enterprises oriented infrastructure like business markets or business incubators that will be beneficial to women enterprises;(3)Support women entrepreneurs to develop linkages and partnerships with large enterprises;(4)Facilitate marketing of products and services of women enterprises in both domestic and in international markets; and (5) Support capacity building of the beneficiaries of the Fund and their institutions.

WEF has achieved the following milestones; (1) It has established its presence in 290 constituencies which has enhanced outreach by facilitating easy access to the credit services;(2) It has a proven lending methodology to groups with loan repayment of over $90 \%$ country wide;(3) WEF has deployed mobile telephone technology for loan repayments which has improved service delivery; (4) Capacity building for women is a precondition to lending. During the first three quarters of the 2013/2014 financial year 29,624 women had been trained in entrepreneurship in all the 290 constituencies (WEF, 2013) ;5) WEF won an achievement award in acknowledgement of her efforts in realizing the 3rd millennium 
development goal on Gender Equality and Women Empowerment at the second MDG awards, 2011; and (5) WEF in collaboration with the Ministry of Cooperatives has facilitated the registration of forty six women owned Sacco's throughout the country.

WEF performs to ensure that women throughout the country are empowered financially and are running enterprises that are steady and contribute to their economic status and thus the country's economy as a whole (WEF, 2012). The fund promotes financial inclusion of women by removing barriers that have prevented them from participating fully in the economic development of the country. Interest free loans are provided to registered self-help groups through respective constituencies. WEF gets a hundred percent financial backing from the Government of Kenya through the annual budgetary allocation.However, its funds dropped from Ksh 352 million in the year 2012 to Ksh 167 million in the year 2013 following the transfer of Ksh 185 million to Uwezo fund as part of devolved funds (KNBS, 2014).Nonetheless, to respond to the increasing demand for her services, WEF is pursuing out collaborative partnerships with similar-minded development organizations for support.

\subsection{Statement of the Problem}

Women entrepreneurs face a myriad of issues, such as inaccessibility to credit, low education levels and cultural barriers in order to succeed in Business. The Women enterprise Fund (WEF) in Kenya was set up in 2007 in order to help women entrepreneurs. One of the mandates of WEF is capacity building through entrepreneurship training, which is offered throughout the country. This study, therefore sought to find out whether the Training offered by the Women Enterprise Fund has effects on the capital and labour resources of women grocery micro-entrepreneurs trained.

\subsection{Objectives of the Study}

The study addressed the following two objectives:

- To determine the effects of WEF's training on capital among women grocery micro-entrepreneurs.

- To establish the effects of WEF's training on labour among women grocery micro-entrepreneurs.

\subsection{Hypotheses of the Study}

The hypotheses were developed in line with the independent variable (WEF's training) and indicators of performance (capital and labour).

- Ho : There are no significant effects of WEF's training on labour among women grocery micro-entrepreneurs.

- $\mathrm{Ho}_{2}$ : There are no significant effects of WEF's training on capital among women grocery micro-entrepreneurs.

\subsection{Limitation of the Study}

Kenya has over 70 Sub-Counties and only one was selected for this study; for this reason the findings may not be generalized to all the Sub-Counties in the country. However, the study would provide an insight into how WEF's training affects the performance of women grocery micro-entrepreneurs.

\subsection{Assumptions of the Study}

The study was based on the following assumptions:

- The respondents were ready and willing to participate in the study by providing honest and accurate information on the issue raised.

- Women in Thika Sub - County engaged in grocery micro-enterprises.

\section{Literature Review}

\subsection{Labour Resource among Women Entrepreneurs}

National MSE Baseline Survey, (2011) executive summary indicates that labour is a critical input for the performance of any enterprise, yet women spend less time than men working in their business and are likely to hire fewer workers due to the impact of gender differentiated allocation of tasks within the household.

Cultural norms defining the respective roles of women and men within the household and society may explain why female-run businesses tend to stay small and having more subsistence leanings. Lack of time due to multiple roles of women constitute another major constrain in women performance in MSE's activities (Mbogo, 2011).Women as the chief custodians of children and responsible for domestic tasks, embrace self-employment because it offers flexible work schedules, and permits them to balance work and family responsibilities. Women spend more time performing domestic tasks such as household chores or child rearing, which can avert a chunk of their best useful time away from marketoriented activities (Jones, McEvoy, \& Barrett, 2008). The gender differentiated allocation of time within the household can cause women to allocate their time sub-optimally to their businesses. The structure of the family may also have an impact on such ineptitudes, as the existence of dependent members can increase the burden of household duties.

Many women operate their business in their homes because it enables them to combine work and family chores (Ypeij, 2000). In addition, in a number of countries, businesses that are in close proximity to home surroundings are often the only opportunity for women to generate income as the prevailing cultural norms prevent them from exercising an activity outside or far away from the household. Home-based dealings carry quite a few drawbacks, like being far-flung from input marketplaces plus clients. Conflict arising from the different roles women have to play in households, including the long times spent at the enterprises site, have been cited as constituting a major obstacle to the development, growth and stability of women owned enterprises in Kenya (Bardasi, Sabarwal, \& Terrell, 2011). 
The use of family members as a Labour resource can act as a double edged sword, in that they provide free or cheap labor and have an interest in the prosperity of the firm, besides using them to execute supervision tasks thus freeing the entrepreneur for other responsibilities (Johnston \& Le Roux, 2007). However, the use of family members can also have antagonistic outcomes: the entrepreneur may feel the pressure to offer work to members of his / her kin group even though they lack the technical skills and qualification. Overall the role of the family in the activity can be positive or negative and may depend on the sex of the businessperson. For instance, women could be more willing than men to hire family workers. Supplementary, the right of use to family labor can be essential for female entrepreneurs in settings where it is difficult for them to hire and supervise male workers (Luke \& Munshi, 2006). Male entrepreneurs depend on the help of their spouse more than women can rely on the labour of their husbands.

From the scholarly works above by the various authors it is critically stated that cultural norms, family responsibilities and family members affect the amount of labour hours that a woman entrepreneur will spend on her enterprise. However, the element of training affecting labour hours spent and hiring of employees is inadequately covered. Therefore, this study filled this gap by examining the effects of WEF's training on labour among women grocery micro entrepreneurs in Thika Sub-County. Basing on the study findings WEF's significantly increased the labour level of microenterprises.

\subsection{Capital Resource among Women Entrepreneurs}

Cultural attitudes towards women have a bearing on women's ability to stand on their own as borrowers of credit from financial institutions (Government of Kenya, 2005). This is because they have limited access to land and other properties ownership. Consequently, they lack adequate collateral security for accessing credit services. The same sessional paper continues to quote that, most of the financial institutions and other facilities are located in urban and peri -urban areas, while majority of women are in rural areas. This factor has led to most women being unfamiliar with institutional banking and credit systems except their own funds (Wanjohi \& Mugure, 2008). This hampers their bid to expand their business, yet they are good in debt servicing.

To obtain credit for her business, a woman is likely to participate in a "merry-go round" group of five or six women who combine their savings over a six-month period of time and then start lending, on a very short-term basis, to members from the pool (Gakure \& Roselyn, 2003). Men have an easier time accessing credit because they are more likely than women to have title deeds to offer as loan collateral. This enables them to function on an "individual" basis more so than women, who must use groups to pool funds.

As argued by De Mel, McKenzie and Woodruff (2009), inefficiencies arising from a lack of cooperation within the household may be responsible for the lower returns to capital in women-run businesses found in Sri Lanka, with one of the spouse seizing part of the profit or working capital of the enterprise for other purposes rather than for the enterprise wellbeing. There is a great need for women entrepreneurs to get access to credit facilities and policy makers should understand and develop successful strategies to address the issue (World Bank, 2012). According to Besley (1995) without adequate access to these credit facilities women entrepreneurs will be subjected to negative shocks and issues such as poor production levels in their businesses, lack of growth and generally poor performance of the businesses. They can also lose some of the few assets they have, unlike their male counterparts who can access well-designed credits and loans easily; thus able to finance their businesses and adopt more effective and efficient strategies to stabilize their businesses (Roomi \& Parrot, 2008).

From the above discussion, various authors have in-depth examined the role negative cultural attitudes, legal frameworks and household responsibilities hamper returns on capital among women entrepreneurs. However, the effects of training on returns on capital among women entrepreneurs is insufficiently discussed. Thus, this study bridged this gap by examining effects of the WEF's training on capital among women grocery micro -entrepreneurs in Thika Sub-County. The study found out that training significantly increases the micro-enterprises capital in the study area.

\subsection{Theoretical Framework}

This study was steered by the Human Capital Theory by Adam Smith (1776). Human capital is defined as the abilities and skills of any person, particularly those learnt through investment in education and training that enhances potential income earning. It is founded on Adam Smith's explanation of wage differentials in net advantages and disadvantages between various occupations. The expenses of learning a skill or trade are a major constituent of the net advantage, ceteris paribus, personal incomes differ according to the degree of investment in human capital; that is, the education and training carried out by individuals (Suvillan \& Steven, 2003). 


\subsection{Conceptual Framework}

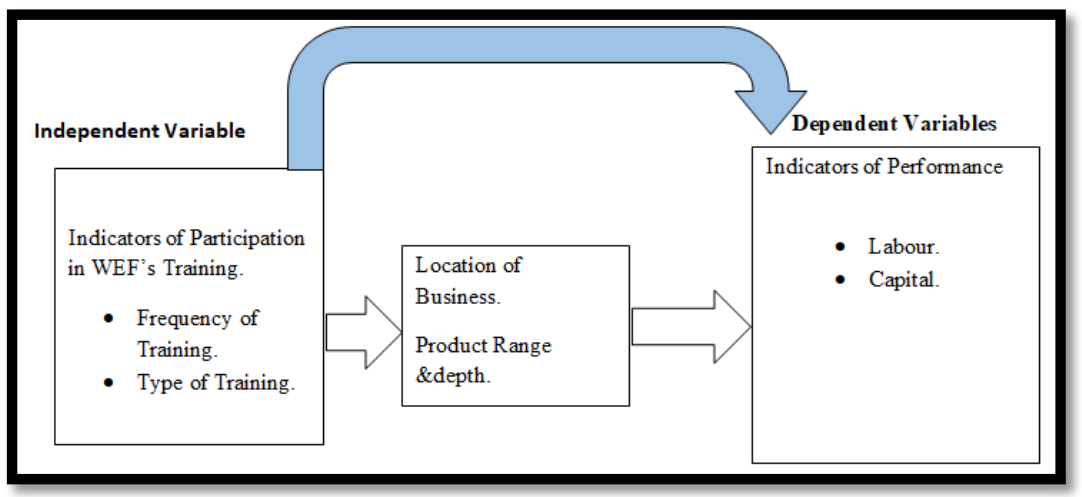

Figure 1: Conceptual Framework

\section{Research Design}

The study was based on a cross-sectional descriptive survey research design to collect data from the respondents in the study area. A cross-sectional descriptive survey is used to describe characteristics/features of a population or phenomenon being studied. It does not answer queries about how/when/why the features occurred. Rather it addresses the "what" question (what are the features of the populace or condition being studied (Creswell, 2007). A cross-sectional descriptive survey method involves gathering data once, during a period of days, weeks or in months, it seeks to ascertain respondents' perspectives or experiences on a definite subject in a preset planned method. The respodents answered questions administered through questionnaires and the researcher described the responses given. The survey involved questions of the past and current situation. The choice of the study design was made based on its ability to determine relationship between two or more variables.

\subsection{Sampling Procedure and Sample Size}

To guarantee that the sample correctly represents the population, Cooper and Schindler (2008) recommend that the researcher must clearly define the characteristic of the population, define the requisite sample size and select the best technique for selecting members of the sample from the larger population.

\subsection{Sample Size Determination}

Kerlinger, (1983) observes that a sample size of $30 \%$ is representative of the population to be studied. Using this as a guide, a sample size of 111 respondents was selected. These women were drawn from five county assembly wards which are within Thika Sub-County.

\begin{tabular}{|c|c|c|c|}
\hline County Assembly Ward & Population & Percentage & Sample \\
\hline Township & 84 & $30 \%$ & 25 \\
\hline Kamenu & 68 & $30 \%$ & 20 \\
\hline Hospital & 76 & $30 \%$ & 23 \\
\hline Gatuanyaga & 65 & $30 \%$ & 20 \\
\hline Ngoliba & 78 & $30 \%$ & 23 \\
\hline Total & 371 & $30 \%$ & 111 \\
\hline
\end{tabular}

Table 1: Sampling Grid

Source: The Women Enterprise Fund

\subsection{Sampling Procedure}

The study used stratified random sampling (the county assemblies ward being the stratas) to get the required sample size of 111 women grocery micro - entrepreneurs. The researcher used excel random sample to select the sample from the target population of 371 women grocery micro - entrepreneurs with WEF's registration number in the different county assemblies.

\section{Findings and Discussions}

\subsection{Age of the Respondents}

The ages of the respondents was categorized as below 18 years, 18-25 years, 26-35 years, 36-45 years, 46-55 years and 55 years and above. Table 3 shows the summary of the results. 


\begin{tabular}{|c|c|c|}
\hline Age in Years & Freq & Percent \\
\hline Below 18 years & 0 & $0.0 \%$ \\
\hline 18-25 years & 9 & $9.1 \%$ \\
\hline $26-35$ years & 27 & $27.3 \%$ \\
\hline 36-45 years & 41 & $39.8 \%$ \\
\hline 46-55 years & 18 & $18.2 \%$ \\
\hline 55 years \& above & 8 & $9.1 \%$ \\
\hline Total & 103 & $100.0 \%$ \\
\hline
\end{tabular}

Table 2: Age of the Respondents in Years

Source (Research, 2016)

It was found that most of the women grocery micro entrepreneurs were aged between 36-45 years as represented by $39.8 \%$ of the respondents. This was closely followed by respondents who were aged between $26-35$ years (27.3\%) and 46 - 55 years (18.2\%). There were few respondents aged 18 - 25 years and on the extreme ends (below 18 years and 55 years and above). The study findings are also in line of Syukurriah Idrus et al. (2013) who found the demographic of the entrepreneur are 50 percent of them between range 30 years old and above.

\subsection{Level of Education of the Respondents}

The distribution of the respondents' highest level of education was as shown on Table 4.

\begin{tabular}{|c|c|c|}
\hline Level of Education & Frequency & Percent \\
\hline No formal schooling & 19 & $19.4 \%$ \\
\hline Primary & 48 & $46.6 \%$ \\
\hline Secondary & 21 & $21.4 \%$ \\
\hline Tertiary & 12 & $12.2 \%$ \\
\hline University & 3 & $3.1 \%$ \\
\hline Total & 103 & $100.0 \%$ \\
\hline
\end{tabular}

Table 3: Highest Level of Education of the Household Head Source (Research, 2016)

The findings of the study indicate that most of the respondents (46.6\%) had primary level of education. The results further indicated that $21.4 \%$ of the respondents had secondary level of education while $19.4 \%$ had no formal education. A few respondents had tertiary and university level of education. These results generally imply that most of the women grocery micro entrepreneurs had inadequate level of education that could hinder them from carrying out their business activities in the study area. These findings are in line with the study by the research by George W. Njoroge and Jagongo Ambrose (2016) who found out that majority of their respondents had only reached the secondary level of education and not highly educated.

\subsection{Effects of WEF's Training on Capital among Women Grocery Micro-Entrepreneurs}

The first objective in this study sought to determine the effects of WEF's training on capital among women grocery micro-entrepreneurs. In order to meet this objective, a null hypothesis, "Ho $\mathrm{H}_{1}$ : There are no significant effects of WEF's training on labour among women grocery micro-entrepreneurs" was formulated and tested using one sample t-test (before \& after comparison) and multivariate regression.

Summarized in Table 17 are the paired samples t-test results for the effects of WEF's training on capital among women grocery micro-entrepreneurs

\begin{tabular}{|c|c|c|c|}
\hline Capital Levels & Mean & Std. Deviation & Std. Error Mean \\
\hline Capital before & 1.851 & .484 & .224 \\
\hline Capital after & 3.964 & .401 & .257 \\
\hline
\end{tabular}

Table 4: Effects of WEF's Training on Capital among Women Grocery Micro-Entrepreneurs

$\mathrm{N}=103$, Mean Difference $=2.113$, Calc. $\mathrm{T}$ value $=3.36$, Critical T value $=1.98, \mathrm{Df}=102, \mathrm{P}-$ Value $=0.000$

The results in Table 4 show that the mean micro-enterprises capital scores for the sampled respondents before the receipt of WEF trainings was 1.851 (with a standard deviation of .484). The mean capital scores for the sampled respondents after the receipt of WEF trainings increased to 3.964 (with a standard deviation of .401) registering a mean gain of 2.113. The mean difference was statistically significant at $5 \%$ level (P-value $=0.000)$ implying that the level of capital realized after the receipt of training was significantly higher than before the receipt of training.

The use of Ordered Logistic Regression was also adopted in determining the effect of WEF's training on the level of capital among women grocery micro-entrepreneurs. This type of regression was adopted because of the ordered nature of dependent variable (business capital). Table 18 summarizes the regression results for this analysis. 


\begin{tabular}{|c|c|c|c|c|}
\hline Capital after Training & Coef. & Std. Err. & $\mathbf{Z}$ & $\mathbf{P}>|\mathbf{z}|$ \\
\hline Number of trainings received & $3.283^{*}$ & 1.673 & 2.74 & 0.000 \\
\hline
\end{tabular}

Table 5: Ordered Logistic Regression for The Effect of WEF's Training on Capital among

Women Grocery Micro-Entrepreneurs

$N=103$, Log Likelihood $=22.793, L R X^{2}(1)=6.19$, Prob $>X^{2}=0.000$, Pseudo $R^{2}=0.490$,

* = Significant at $5 \%$ Level

The log likelihood for the fitted model of 22.793 and the Likelihood Ratio chi-squared value of 6.19 indicate that the parameters (capital after training and the number of trainings received) are jointly significant at $5 \%$. Pseudo $\mathrm{R}^{2}$ of 0.490 meet the statistical threshold of $20 \%$ confirming that the capital realized after WEF training was well attributed to the number of trainings received by women grocery micro-entrepreneurs. The results reveal the coefficient for the number of trainings received (3.283) as positive and statistically significant at 5\%. This implies that WEF training significantly increases the micro-enterprises capital in the study area. Based on these results, the null hypothesis, "There are no significant effects of WEF's training on capital among women grocery micro-entrepreneurs" was rejected.

\subsection{Effects of WEF's Training on Labour among Women Grocery Micro-Entrepreneurs}

The second objective in this study sought to establish the effects of WEF's training on labour among women grocery micro-entrepreneurs. In order to meet this objective, a null hypothesis, "Ho 4 : There are no significant effects of WEF's training on labour among women grocery micro-entrepreneurs" was formulated.

Table 6 summarizes the paired samples t-test results for the difference in mean labour endowment by the sampled microenterprises before and after the WEF's training in the study area.

\begin{tabular}{|c|c|c|c|}
\hline Levels of Labour & Mean & Std. Deviation & Std. Error Mean \\
\hline Labour before & 1.944 & .522 & .193 \\
\hline Labour after & 2.865 & .912 & .185 \\
\hline
\end{tabular}

Table 6: Effects of WEF's Training on Labour among Women Grocery Micro-Entrepreneurs

$N=103$, Mean Difference $=0.921$, Calc. $T$ Value $=2.65$, Critical $T$ Value $=1.98, D f=102, P-$ Value $=0.025$

The mean score for the monthly micro-enterprises labour endowment before and after the WEF training was 1.944 (with a standard deviation of .522) and 2.865 (with a standard deviation of .912), respectively. The mean difference in the labour endowment scores (0.921) was statistically significant at $5 \%$ level ( $\mathrm{P}$-value $=0.025$ and $\mathrm{T}$ value $=2.65$ ). This implies that as a result of WEF's training the micro-enterprises labour endowment significantly increases. Women grocery micro-enterprises whose entrepreneurs employed more workers.

The Ordered Logistic Regression results was used in determining the effect of WEF's training on labour among women grocery micro-entrepreneurs. The regression results are summarized in table 7.

\begin{tabular}{|c|c|c|c|c|}
\hline Labour after Training & Coef. & Std. Err. & $\mathbf{Z}$ & $\mathbf{P}>|\mathbf{z}|$ \\
\hline Number of trainings received & $2.779 *$ & 1.530 & 2.64 & 0.006 \\
\hline
\end{tabular}

Table 20 shows that the two parameters included in the regression model (micro-enterprises capital and number of trainings received) were jointly significant at 5\% since the log likelihood (24.910) and the Likelihood Ratio (LR) chisquared value of 5.24 were significant at $5 \%$. Pseudo $\mathrm{R}^{2}$ of 0.386 was well above the $20 \%$ threshold indicating that the number of trainings received by women grocery micro-entrepreneurs among the sampled micro-enterprises significantly explained the variation in labour after training.

The coefficient for the number of trainings received was positive and statistically significant at $5 \%$ ( $\mathrm{p}$-value $=$ 0.006) implying that WEF's training had a significant effects on labour among women grocery micro-entrepreneurs. Therefore, the null hypothesis, "There are no significant effects of WEF's training on capital among women grocery microentrepreneurs" was rejected. Trainings by WEF significantly increased the labour level of micro-enterprises. The findings are in line with those of S.D. Barwa (2003 pg. xviii) who found out that impact of start your business training led to increasing business sales and income, employment and other aspects of women's businesses

\subsection{Discussions in Relations with Other Research Studies}

This section discusses the findings above in relation to other research findings. The study findings are in agreement with (Charitoneko, 1998) who noted that loans enable women to invest in and expand their business. The findings of this study differ from those of (Rhyne \& Otero, 1992) who reported that some of the women entrepreneurs are willing only to save, not to borrow. Just like the findings of (Akanji, 2006; Kuzilwa, 2005) this study established that training is a very important component for women entrepreneurs as it provides the skills and experience needed for 
business. In summary, the findings of this study are in line with those of (Mayoux, 2001) who suggests that micro finance institutions brings about increased income due to accessibility of micro credit and training on how to manage it.

The study findings are also similar to those of (UNIDO, 2003) who noted that women micro-entrepreneurs have an inability to judge the profitability of their operations due to a lack of basic accounting skills, insufficient technical and business management skills as well as socio-cultural constraints. The study results are also in line with those (McGrath \& King, 2002) who stated that training is one of the factors that can impact positively on the growth of enterprises. Those women entrepreneurs with a greater capacity of human capital, in terms of education and (or) occupational training, are well positioned to acclimatize their enterprises to constantly changing business environments and cycles.

\section{Summary of Results}

\subsection{Effects of WEF's Training on Capital among Women Grocery Micro-Entrepreneurs}

The results in Table 17 show that the mean micro-enterprises capital scores for the sampled respondents before the receipt of WEF trainings was 1.851 (with a standard deviation of .484). The mean capital scores for the sampled respondents after the receipt of WEF trainings increased to 3.964 (with a standard deviation of .401) registering a mean gain of 2.113. The mean difference was statistically significant at $5 \%$ level (P-value $=0.000)$ implying that the level of capital realized after the receipt of training was significantly higher than before the receipt of training. The coefficient for the number of trainings received (3.283) as positive and statistically significant at 5\%. This implies that WEF training significantly increases the micro-enterprises capital in the study area. Based on these results, the null hypothesis, "There are no significant effects of WEF's training on capital among women grocery micro-entrepreneurs" was rejected.

\subsection{Effects of WEF's Training on Labour among Women Grocery Micro-Entrepreneurs}

The mean score for the monthly micro-enterprises labour endowment before and after the WEF training was 1.944 (with a standard deviation of .522) and 2.865 (with a standard deviation of .912), respectively. The mean difference in the labour endowment scores (0.921) was statistically significant at $5 \%$ level ( $\mathrm{P}$-value $=0.025$ and $\mathrm{T}$ value $=2.65$ ). This implies that as a result of WEF's training the micro-enterprises labour endowment significantly increases. Women grocery micro-enterprises entrepreneurs employed more workers. The coefficient for the number of trainings received was positive and statistically significant at $5 \%$ (p-value $=0.006$ ) implying that WEF's training had a significant effects on capital among women grocery micro-entrepreneurs. Therefore, the null hypothesis, "There are no significant effects of WEF's training on capital among women grocery micro-entrepreneurs" was rejected. Trainings by WEF significantly increased the capital level of micro-enterprises.

\subsection{Conclusions}

- The level of capital realized after the receipt of training was significantly higher than before the receipt of training. WEF's training had statistically significant effects on capital among women grocery micro-entrepreneurs.

- WEF's training significantly increased the micro-enterprises labour endowment. Women grocery microenterprises whose entrepreneurs were trained were able to employed more workers. WEF's training had significant effects on capital among women grocery micro-entrepreneurs.

\subsection{Policy Recommendations}

In view of the findings and the conclusion drawn above, this study makes the following recommendations:

- Women micro-entrepreneurs in the study area should be encouraged to take advantage of WEF's training in order to increase their profits.

- Women micro-entrepreneurs in the study area should be encouraged to take advantage of WEF's training in order to increase their sales.

- Women micro-entrepreneurs in the study area should be encouraged to take advantage of WEF's training in order to increase their ability to employ more workers.

\subsection{Suggestions for Further Research}

The findings of this study would act as a base for more research on the effects of Women Enterprise Fund's training on performance of women grocery micro-entrepreneurs in Thika Sub-County, Kiambu County. This study was not exhaustive and recommends further research on:

- The effect of Women Enterprise Fund's training on women grocery micro-enterprises stability in the study area.

- The effect of Women Enterprise Fund's training on women grocery micro-enterprises product range and depth in the study area.

\section{References}

i. Akanji, O. 0. (2006). Microfinance as a strategy for poverty reduction. Central Bank of Nigeria, Economic and Financial Review.

ii. Aldrich H. E. (2007). Organizations and environments. Englewood Cliffs, NJ: Prentice-Hall.

iii. Bardasi.E, Sabarwal, S., \& Terrell, K. (2011). 'How do Female Entrepreneurs Perform? Evidence from Three Developing Regions', Small Business Economics, 37(4), pp. 417-441

iv. Besley, T. (1995). Savings, credit, and insurance: The handbook of development economics. The Netherlands. Amsterdam. 
v. Charitoneko, Stephanie \& Fruman, Cecile \& Pederson, Glen (1998). Case Studies in Microfinance, Kenya Rural Enterprise Program, August 1998.

vi. Creswell, J.W (2007) Research Design: Quantitative, Qualitative and Mixed Approaches, Sage Publishers, London

vii. De Mel, S., McKenzie, D., \& Woodruff. (2009). 'Are Women more Credit Constrained? Experimental Evidence on Gender and Microenterprise Returns', American Economic Journal: Applied Economics.

viii. Gakure \& Roselyn. (2003). "Factors Affecting Women Entrepreneurs' Growth Prospects in Kenya." Prepared for the International Labour Organization (ILO), Geneva, November.

ix. Gatara, T.H. (2010).Introduction to research methodology. Olive Publishing Co. Nairobi, Kenya.

x. Government of Kenya. Sessional Paper No. 2. (2005). Development of Micro and Small Enterprises for Wealth and Employment Creation for Poverty Reduction: Government Printer.

xi. Kerlinger, F.N. (1983). Foundations of Behavioural Research (2nd Edition). Holt, Rinehart and Winston: New York.

xii. Kuzilwa, J. (2005). The role of credit for small business success: A study of the National Entrepreneurship Development Fund in Tanzania. The Journal of Entrepreneurship, 14 (2), 131-161.

xiii. Mayoux L. (2001). Impact assessment of microfinance: Towards a sustainable learning process. Enterprise Development Impact Assessment Service (EDIAS).

xiv. McGrath, S., \& King, K. (2002). "Learning to Complete African Education, Training and Small Enterprises Development in Error Of Globalization." Papers on Education Training and Enterprises No.1, Center For African Studies: University of Edinburgh.

xv. Rhyne, Elisabeth \& Otero, Maria (1992). Financial Services for Microenterprises: Principles and Institutions. World Development 20/11

xvi. Roomi, M. A., \& Parrot, G. (2008). Barriers to development and progression of women entrepreneurs in Pakistan. The Journal of Entrepreneurship, 17 (1), 59-72.

xvii. S. D. Barwa (2003), ILO VIETNAM WORKING PAPER SERIES NO. 1Impact of Start Your Business (SYB) Training on Women Entrepreneurs in Vietnam; International Labour Organization (ILO)

xviii. UNIDO, (2003). “A path of poverty: Developing rural women entrepreneurship.” Economy

xix. United Nations Economic and Social Commission for Asia and the Pacific (UNESCAP, 2007).

xx. World Bank. (2012). World Development Report 2012: Gender Equality and Development, World Bank, Washington DC.

xxi. World Bank. (2012). World Development Report 2012: Gender Equality and Development, World Bank, Washington DC. 